\title{
Expression of transcription factor AP-2 in colorectal adenomas and adenocarcinomas; comparison of immunohistochemistry and in situ hybridisation
}

\author{
K M Ropponen, J K Kellokoski, R T Pirinen, K I Moisio, M J Eskelinen, E M Alhava, \\ V-M Kosma
}

\begin{abstract}
Aims-To investigate whether the three different AP-2 isoforms are expressed differently in colorectal adenomas and carcinomas.

Methods-The study comprised 43 randomly selected patients diagnosed and treated at Kuopio University Hospital in 1996 for colorectal adenocarcinoma $(n=30)$ and colorectal adenoma $(n=13)$. The expression of AP- $2 \alpha, \mathrm{AP}-2 \beta$, and AP- $2 \gamma$ was analysed by immunohistochemistry (IHC) and the mRNA status of AP-2 $\alpha$ was determined by in situ hybridisation (ISH) and confirmed by reverse transcription polymerase chain reaction (RT-PCR). AP-2 expression patterns were correlated with clinicopathological variables.

Results-In adenomas and carcinomas, AP-2 $\beta$ cytoplasmic positivity was higher than that of AP-2 $\alpha$ or AP-2 $\gamma$ AP-2 $\alpha$ expression was reduced in advanced Dukes's stage carcinomas. In high grade carcinomas, both AP-2 $\alpha$ and AP- $2 \gamma$ expression was reduced. ISH demonstrated increased AP- $2 \alpha$ values in high grade carcinomas. Seven of 30 carcinoma specimens displayed a moderate or strong mRNA signal, despite being negative for AP-2 $\alpha$ protein. RT-PCR from AP-2 $\alpha$ mRNA and protein positive tumours confirmed that the positive signal in ISH originated from the exon 2 of TFAP2A.

Conclusions-AP-2 $\alpha$ was reduced in advanced Dukes's stage adenocarcinomas. Together with reduced AP- $2 \gamma$ expression in high grade carcinomas, this might contribute to tumour progression. The discrepancy between mRNA and protein expression suggests that posttranscriptional regulatory mechanisms might modify the availability of functional AP-2 $\alpha$ protein in colorectal carcinoma. (f Clin Pathol 2001;54:533-538)
\end{abstract}

Keywords: AP-2 proteins; immunohistochemistry; in situ hybridisation; colorectal neoplasms

The transcription factor AP-2 was originally identified as a nuclear factor regulating the expression of human metallothionein IIa. ${ }^{1}$ $\mathrm{AP}-2$ has also been reported to be involved in the regulation of various genes, including those encoding p21, c-KIT, MCAM (MUC18), type
IV collagenase, c-MYC, c-erbB-2, E-cadherin, and the cytokeratins. ${ }^{2-9}$ In addition, AP-2 has a role in the embryonal development of the hindbrain, spinal cord, face, and limbs. ${ }^{10}$ Loss of AP-2 gene function can result in severe deformities within tissues of ectodermal origin. ${ }^{2}$

The AP-2 family of transcription factors consists of three homologous $50 \mathrm{kDa}$ proteins-AP- $2 \alpha, \mathrm{AP}-2 \beta$, and $\mathrm{AP}-2 \gamma$ - which are encoded by separate genes. ${ }^{11}$ The AP- $2 \alpha$, $\mathrm{AP}-\beta$, and $\mathrm{AP}-\gamma$ genes are located at chromosomes $6 \mathrm{p} 24,6 \mathrm{p} 12$, and $20 \mathrm{q} 13$, respectively. ${ }^{12}$ The chromosomal location of AP- $2 \alpha$ (6p2422.3) has been reported to be a frequent site for loss of heterozygosity in cancer. ${ }^{13-16} \mathrm{AP}-2$ has also been shown to activate p21 expression, providing a link between differentiation and negative cell cycle control. ${ }^{12}$ However, the mechanisms by which AP-2 is involved in normal development and the regulation of terminal differentiation of cells are mostly unknown.

Recently, a decrease in AP-2 immunopositivity has been described in cervical intraepithelial neoplasia. ${ }^{17}$ In addition, AP-2 expression was decreased within human malignant melanoma tumours compared with the strongly immunopositive normal adjacent epidermis. ${ }^{3}$ In stage I cutaneous malignant melanoma, reduced AP-2 expression correlated with malignant transformation and tumour progression. ${ }^{18}$ Similar results have been described in ovarian cancer, in which loss of cytoplasmic AP- $2 \alpha$ has been associated with poor survival, ${ }^{19}$ and the loss of $\mathrm{AP}-2 \alpha$ and $\mathrm{AP}-2 \beta$ has been associated with disease progression in breast cancer. ${ }^{11}$

To the best of our knowledge, the expression of $\mathrm{AP}-2 \alpha, \mathrm{AP}-2 \beta$, and $\mathrm{AP}-2 \gamma$ has not been studied previously in colorectal carcinomas and adenomas. Therefore, we analysed the expression of AP- $2 \alpha$ by in situ hybridisation (ISH) and reverse transcription polymerase chain reaction (RT-PCR); we also analysed $\mathrm{AP}-2 \alpha, \mathrm{AP}-2 \beta$, and $\mathrm{AP}-2 \gamma$ proteins by immunohistochemistry (ICH) to compare these methods and to clarify the role of AP-2 expression in colorectal cancer progression.

\section{Methods}

PATIENTS

Our study consisted of 30 randomly selected patients diagnosed and treated at Kuopio University Hospital for colorectal adenocarcinoma in 1996 and 13 patients with colorectal 
Table 1 Clinicopathological data of the patients

\begin{tabular}{ll}
\hline Variable & \\
\hline Age (years) & Range: 38-91; mean: 71 \\
Sex & Females/males: 25/18 \\
Carcinomas & 30 \\
Tumour site & \\
Caecum & 4 \\
Ascending colon & 3 \\
Transverse colon & 8 \\
Descending colon & 2 \\
Sigmoid colon & 7 \\
Rectum & 6 \\
TNM category & $3 / 1 / 23 / 3$ \\
T: $1 / 2 / 3 / 4$ & $13 / 13 / 4$ \\
N: $0 / 1 / 2$ & $24 / 6$ \\
M: $0 / 1$ & $4 / 9 / 11 / 6$ \\
Dukes's: A/B/C/D & $8 / 17 / 5$ \\
Histological grade: $1 / 2 / 3$ & 13 \\
Adenomas & 5 \\
Mild dysplasia (1) & 7 \\
Moderate dysplasia (2) & 1 \\
Severe dysplasia (3) & \\
\hline
\end{tabular}

adenoma. The clinical staging of all tumours was completed according to the UICC $(1997)^{20}$ and modified Dukes's classifications. ${ }^{21}$ Table 1 summarises the pertinent data on the patients.

HISTOLOGICAL METHODS

The tumour samples obtained during surgery were immediately fixed in $10 \%$ buffered formalin ( $\mathrm{pH} 7.0$ ), and later embedded in paraffin wax. Several original sections from each of the primary tumours were re-examined by two observers unaware of the clinical data or the disease outcome, and the most representative tissue block (the most malignant section of the tumour) was selected, cut at $5 \mu \mathrm{m}$ thickness, and stained with haematoxylin and eosin (HE). Tumours were graded as well (grade 1), moderately (grade 2), or poorly (grade 3) differentiated (WHO grade). In adenomas, dysplasia was graded as mild (1), moderate (2), or severe (3). Table 1 gives the patients' histopathological data.

IHC DETECTION OF AP-2

Paraffin wax embedded sections $(5 \mu \mathrm{m}$ thick) were rehydrated and washed twice for five minutes with phosphate buffered saline (PBS). The sections were heated in a microwave oven in $0.05 \mathrm{~mol} /$ litre Tris/ $\mathrm{HCl}$ buffer $(\mathrm{pH} \mathrm{9.7)} \mathrm{for}$ two times five minutes. Endogenous peroxidase activity was blocked with $5 \% \mathrm{H}_{2} \mathrm{O}_{2}$ for five minutes, followed by two washes (five minutes each) with PBS. The tissue sections were incubated overnight at $4^{\circ} \mathrm{C}$ with a primary antibody. A rabbit polyclonal anti-AP-2 $\alpha$ (C$18)$, anti-AP- $\beta$ (C-20), or anti-AP- $\gamma$ (T-17) (Santa Cruz Biotechnology, Santa Cruz, California, USA) antibody was used at a working dilution of $1 / 1000$ for AP-2 $\alpha, 1 / 100$ for AP-2 $\beta$, and $1 / 200$ for AP- $2 \gamma$. The slides were incubated with the secondary antibody for $30 \mathrm{~min}$ utes and washed twice for five minutes with PBS. The slides were then incubated for 40 minutes in preformed avidin-biotin peroxidase complex (ABC, Vectastain Elite kit; Vector, Burlingame, California, USA) and washed twice for five minutes with PBS. Colour was developed with diaminobenzidine tetrahydrochloride (DAB) (Sigma, St Louis, Missouri, USA). The slides were counterstained with
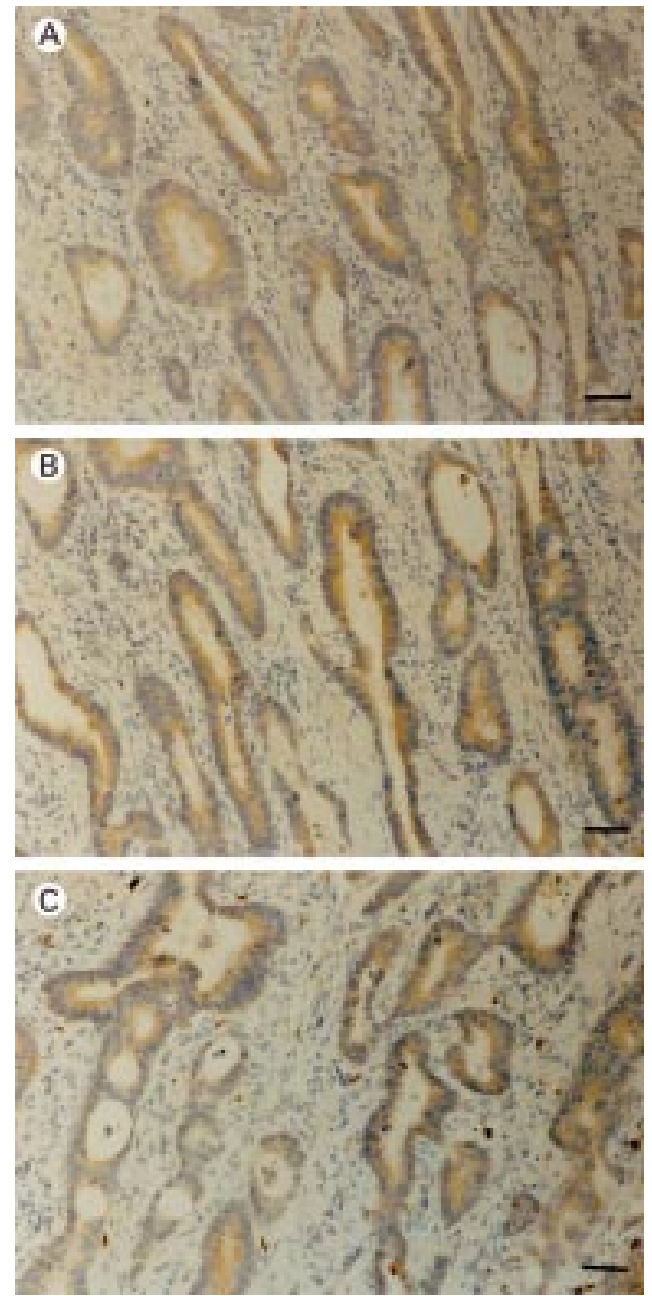

Figure 1 AP-2 immunohistochemical analysis: diffuse cytoplasmic (A) $A P-2 \alpha$, (B) $A P-2 \beta$, and (C) $A P-2 \gamma$ expression in colorectal adenocarcinoma cells. Bar, $60 \mu \mathrm{m}$.

Mayer's haematoxylin, dehydrated, cleared, and mounted with DePex (BDH Limited, Poole, Dorset, UK). A corresponding section processed without the primary antibody was used as a negative control and the inflammatory cells within the tumour served as positive internal controls.

All slides were evaluated with a microscope (field diameter, $490 \mu \mathrm{m}$ ) and the fraction of positive tumour cells was assessed as the percentage of the whole carcinoma or adenoma area by three observers (KMR, JKK, and $\mathrm{V}-\mathrm{MK}$ ) who were unaware of the clinical data of the patients. Discrepancies between the observers were found in less than $10 \%$ of the slides examined, and consensus was reached on further review. The cytoplasmic positivity for $\mathrm{AP}-2 \alpha, \mathrm{AP}-2 \beta$, and $\mathrm{AP}-2 \gamma$ was recorded. When over $50 \%$ positivity in tumour epithelium was noted staining was considered to be diffuse. $\mathrm{AP}-2 \alpha$ positive nuclei were also evaluated, both in adenomas and carcinomas.

MRNA IN SITU HYBRIDISATION

For ISH, we used sections that were consecutive with those used for ICH. Sections $(5 \mu \mathrm{m}$ thick) were dewaxed in xylene and graded alcohols. The sections were rinsed in $0.85 \%$ 
Table 2 AP-2 $\alpha, A P-2 \beta$, and $A P-2 \gamma$ protein and $A P-2 \alpha m R N A$ expression and histological features of the carcinomas

\begin{tabular}{|c|c|c|c|c|c|c|}
\hline Case & $\begin{array}{l}\text { Dukes's } \\
\text { grade }\end{array}$ & $\begin{array}{l}\text { Histological } \\
\text { grade }\end{array}$ & $\begin{array}{l}\text { AP-2a } \\
\text { protein } \\
\text { expression }\end{array}$ & $\begin{array}{l}\text { AP- } 2 \beta \\
\text { protein } \\
\text { expression }\end{array}$ & $\begin{array}{l}\text { AP- } 2 \gamma \\
\text { protein } \\
\text { expression }\end{array}$ & $\begin{array}{l}A P-2 a \\
m R N A \\
\text { expression }\end{array}$ \\
\hline 1 & B & 2 & $10 \%$ & $20 \%$ & $5 \%$ & ++ \\
\hline 2 & $\mathrm{D}$ & 3 & $0 \%$ & $50 \%$ & $10 \%$ & ++ \\
\hline 3 & C & 2 & $0 \%$ & $60 \%$ & $20 \%$ & +++ \\
\hline 4 & D & 2 & $10 \%$ & $35 \%$ & $5 \%$ & $+++\ddagger$ \\
\hline 5 & D & 2 & $0 \%$ & $10 \%$ & $10 \%$ & + \\
\hline 6 & C & 2 & $0 \%$ & $35 \%$ & $10 \%$ & ++ \\
\hline 7 & D & 2 & $0 \%$ & $10 \%$ & $10 \%$ & + \\
\hline 8 & C & 3 & $0 \%$ & $60 \%$ & $5 \%$ & ++ \\
\hline 9 & C & 1 & $5 \%$ & $70 \%$ & $20 \%$ & ++ \\
\hline 10 & C & 3 & $0 \%$ & $10 \%$ & $0 \%$ & ++ \\
\hline 11 & B & 2 & $10 \%$ & $70 \%$ & $20 \%$ & $+^{\star}$ \\
\hline 12 & A & 2 & $80 \%$ & $100 \%$ & $20 \%$ & + \\
\hline 13 & B & 2 & $20 \%$ & $70 \%$ & $60 \%$ & $++^{\star}$ \\
\hline 14 & B & 3 & $30 \%$ & $30 \%$ & $20 \%$ & $++^{\star} \ddagger$ \\
\hline 15 & A & 2 & $80 \%$ & $45 \%$ & $5 \%$ & ++ \\
\hline 16 & C & 2 & $70 \%$ & $70 \%$ & $60 \%$ & + \\
\hline 17 & A & 2 & $0 \%$ & $20 \%$ & $15 \%$ & + \\
\hline 18 & C & 2 & $30 \%$ & $40 \%$ & $5 \%$ & +++ \\
\hline 19 & $\mathrm{C}$ & 1 & $20 \%$ & $60 \%$ & $40 \%$ & $+^{\star}$ \\
\hline 20 & B & 2 & $90 \%$ & $15 \%$ & $10 \%$ & $++^{\star} \neq$ \\
\hline 21 & D & 2 & $0 \%$ & $35 \%$ & $5 \%$ & $-^{\star}$ \\
\hline 22 & B & 1 & $5 \%$ & $10 \%$ & $30 \%$ & $+^{\star} \ddagger$ \\
\hline 23 & A & 1 & $80 \%$ & $80 \%$ & $80 \%$ & + \\
\hline 24 & C & 1 & $10 \%$ & $80 \%$ & $70 \%$ & $+\star \star$ \\
\hline 25 & D & 1 & $0 \%$ & $40 \%$ & $10 \%$ & ++ \\
\hline 26 & $\mathrm{C}$ & 3 & $0 \%$ & $0 \%$ & $0 \%$ & ++ \\
\hline 27 & B & 2 & $20 \%$ & $80 \%$ & $30 \%$ & + \\
\hline 28 & C & 1 & $60 \%$ & $80 \%$ & $80 \%$ & $+++\star$ \\
\hline 29 & B & 1 & $30 \%$ & $80 \%$ & $30 \%$ & $++^{\star}$ \\
\hline 30 & B & 2 & $0 \%$ & $5 \%$ & $5 \%$ & + \\
\hline
\end{tabular}

${ }^{\star}$ Corresponding mRNA and protein positive and negative areas; $¥ \mathrm{AP}-2 \alpha$ positivity in $<5 \%$ of nuclei.

The percentages presented describe cytoplasmic staining in tumour cells.

mRNA expression: - , negative; + , focally positive; ++ , diffusely positive, moderate; +++ , diffusely positive, strong.

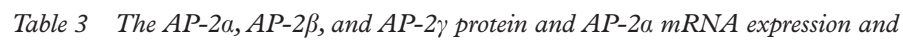
histological features of the adenomas

\begin{tabular}{|c|c|c|c|c|c|}
\hline Case & $\begin{array}{l}\text { Degree of } \\
\text { dysplasia }\end{array}$ & $\begin{array}{l}\text { AP-2a protein } \\
\text { expression }\end{array}$ & $\begin{array}{l}A P-2 \beta \text { protein } \\
\text { expression }\end{array}$ & $\begin{array}{l}\text { AP- } 2 \gamma \text { protein } \\
\text { expression }\end{array}$ & $\begin{array}{l}\text { AP-2a mRNA } \\
\text { expression }\end{array}$ \\
\hline 1 & 1 & $0 \%$ & $80 \%$ & $10 \%$ & + \\
\hline 2 & 2 & $40 \%$ & $70 \%$ & $40 \%$ & $++^{\star} \ddagger$ \\
\hline 3 & 2 & $60 \%$ & $60 \%$ & $10 \%$ & $+++^{\star} \neq$ \\
\hline 4 & 3 & $30 \%$ & $10 \%$ & $30 \%$ & $t^{\star}$ \\
\hline 5 & 2 & $20 \%$ & $60 \%$ & $10 \%$ & + \\
\hline 6 & 2 & $10 \%$ & $70 \%$ & $10 \%$ & $+^{\star}$ \\
\hline 7 & 2 & $10 \%$ & $30 \%$ & $20 \%$ & + \\
\hline 8 & 1 & $20 \%$ & $20 \%$ & $5 \%$ & + \\
\hline 9 & 2 & $30 \%$ & $60 \%$ & $0 \%$ & $++^{\star} \neq$ \\
\hline 10 & 1 & $70 \%$ & $20 \%$ & $0 \%$ & + \\
\hline 11 & 2 & $30 \%$ & $80 \%$ & $60 \%$ & $+^{\star}$ \\
\hline 12 & 1 & $30 \%$ & $50 \%$ & $0 \%$ & - \\
\hline 13 & 1 & $10 \%$ & $85 \%$ & $20 \%$ & - \\
\hline
\end{tabular}

${ }^{\star}$ Corresponding mRNA protein positive and negative areas; $\ddagger \mathrm{AP}-2 \alpha$ positivity in $<5 \%$ of nuclei. The percentages presented describe cytoplasmic staining in adenoma cells. mRNA expression: - , negative; + , focally positive; ++ , diffusely positive, moderate; +++ , diffusely positive, strong.
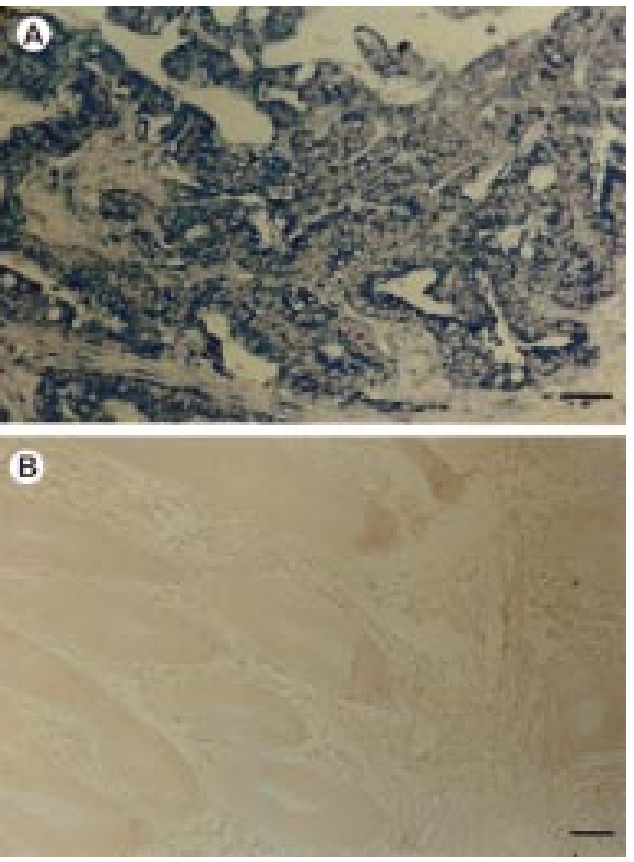

Figure 2 (A) $m R N A$ in situ hybridisation analysis showing strong diffuse $(+++) A P-2 \alpha$ expression in colorectal adenocarcinoma and (B) negative control. Bar, $60 \mu \mathrm{m}$.

biochemistry and molecular biology, Pennsylvania State University, USA) in a pBluescript $\mathrm{KS}+$ vector was linearised to generate antisense and sense digoxigenin labelled probes using the DIG RNA labelling kit (Boehringer Mannheim). Probes were added to the hybridisation buffer at $3.5 \mathrm{ng} / \mu \mathrm{l}$, and the sections were hybridised overnight at $62^{\circ} \mathrm{C}$ in a humidified chamber. Subsequently, sections were washed in buffers with increasing stringency (from $2 \times$ to $0.2 \times$ saline sodium citrate at $57^{\circ} \mathrm{C}$ ). Non-specific binding was blocked with $2 \%$ normal sheep serum in Tris buffered saline. Hybridisation signals were detected by incubation overnight in antidigoxigenin alkaline phosphatase conjugate (Boehringer Mannheim) at 1/1000, followed by nitroblue tetrazolium(NBT)/BCIP for one hour. The reaction was stopped by diluting with water and sections were dehydrated and coverslipped with Mountex (Histolab Production AB, Sweden). The sense probe served as a negative control. ISH staining was graded as negative $(-)$, focally positive $(+)$, and diffusely positive (moderate and strong) $(++$ and +++$)$.

$0.01 \mathrm{M}$ citrate buffer $(\mathrm{pH}$ 6.0) for five minutes. The sections were cooled in the same buffer for 20 minutes and rinsed with PBS for five minutes. The sections were then fixed in $4 \%$ paraformaldehyde and rinsed twice in PBS for five minutes. The sections were pretreated with $0.1 \mathrm{M} \mathrm{HCl}$ for 10 minutes and digested for 20 minutes by proteinase $\mathrm{K}$ (Boehringer Mannheim, Mannheim, Germany) at a concentration of $20 \mu \mathrm{g} / \mathrm{ml}$. After rinsing with PBS and fixation in $4 \%$ paraformaldehyde, the sections were dehydrated in a series of graded alcohols and air dried. All sections were then prehybridised for two hours at $62^{\circ} \mathrm{C}$. Recombinant plasmid pHAP2-Hsma containing human AP- $2 \alpha$ exon 2 (transactivation domain) (kindly donated by Dr Mitchell from the department of

\section{RT-PCR AMPLIFICATION}

For the expression of AP-2 $\alpha$, total cellular RNA was extracted from $20 \mu \mathrm{m}$ thick paraffin wax embedded tissue sections of the tumour, as described previously by Sugg et al..$^{22}$ The RNA was used as a template to synthesise first strand cDNA, and PCR amplification was performed using the enhanced avian RT-PCR kit (Sigma, St Louis, USA). The primers for AP- $2 \alpha$ were designed in our laboratory and commercially synthesised (MedProbe, Oslo, Norway). The specific primers used were: 5'GCCCCGTGTCCCT GTCCAA-3' and 5'TGAGGAGCGAGA GGCGACC-3'. The PCR conditions were as described in the 


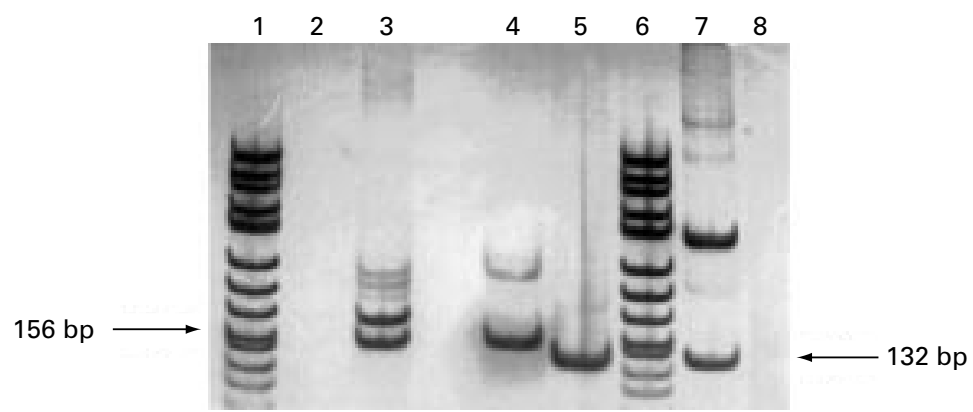

Figure 3 Reverse transcription polymerase chain reaction (RT-PCR) analysis of AP-2a expression was performed on the following extracts: lanes 1 and 6, x174 DNA/Hin FI marker $(0.4 \mu \mathrm{g})$; lane 2 , a negative PCR control for $\beta$ actin in which the template was replaced by water; lane 3, a positive control for $\beta$ actin RNA (from Clontech human placenta cDNA library); lane 4, case number 28 contains a PCR product of the same molecular size (156 bp; $\beta$ actin) as the positive control sample; lane 5, case number 28 contains a PCR product of the same molecular size (132 bp;AP-2a) as the positive control sample; lane 7, positive control sample (from HeLa cDNA; AP-2a); lane 8, a negative $P C R$ control for $A P-2 a$ in which the template was replaced by water.

Table 4 Correlation between $A P-2 a, A P-2 \beta, A P-2 \gamma$, and AP-2a ISH and Dukes's classification and histological grade

\begin{tabular}{|c|c|c|c|c|c|}
\hline & \multicolumn{4}{|c|}{ Dukes's classification } & \\
\hline & $A(n)$ & $B(n)$ & $C(n)$ & $D(n)$ & \\
\hline \multicolumn{6}{|l|}{$A P-2 a$} \\
\hline$<10 \%$ & 1 & 1 & 8 & 5 & $\chi^{2}=10.4$ \\
\hline \multirow{2}{*}{\multicolumn{6}{|c|}{$\begin{array}{l}\geqslant 10 \% \\
A P-2 \beta\end{array}$}} \\
\hline & & & & & \\
\hline$<45 \%$ & 1 & 5 & 4 & 5 & $\chi^{2}=1.76$ \\
\hline$\geqslant 45 \%$ & 3 & 4 & 7 & 1 & $\mathrm{p}=0.19$ \\
\hline \multicolumn{6}{|l|}{$A P-2 \gamma$} \\
\hline$<15 \%$ & 2 & 3 & 5 & 5 & $\chi^{2}=1.75$ \\
\hline$\geqslant 15 \%$ & 2 & 6 & 6 & 1 & $\mathrm{p}=0.19$ \\
\hline \multicolumn{6}{|l|}{$A P-2 a$ ISH } \\
\hline \multirow{4}{*}{$++/+++$} & 3 & 4 & 3 & 3 & $\chi^{2}=2.9$ \\
\hline & 1 & 5 & 8 & 3 & $\tilde{\mathrm{p}}=0.40$ \\
\hline & \multicolumn{3}{|c|}{ Histological grade } & & \\
\hline & $1(n)$ & $2(n)$ & $3(n)$ & & \\
\hline \multicolumn{6}{|l|}{$A P-2 a$} \\
\hline$<10 \%$ & 3 & 7 & 5 & $\chi^{2}=6.04$ & \\
\hline$\geqslant 10 \%$ & 5 & 10 & & $\tilde{\mathrm{p}}=0.04$ & \\
\hline \multicolumn{5}{|l|}{$A P-2 \beta$} & \\
\hline $\begin{array}{l}<45 \% \\
\geqslant 45 \%\end{array}$ & 6 & 7 & $\begin{array}{l}3 \\
2\end{array}$ & $\begin{array}{l}x=1.9 \\
\mathrm{p}=0.17\end{array}$ & \\
\hline \multicolumn{6}{|l|}{$A P-2 \gamma$} \\
\hline$<15 \%$ & 1 & 10 & 4 & $\chi^{2}=6.17$ & \\
\hline \multirow{2}{*}{\multicolumn{6}{|c|}{$A P-2 a$ ISH }} \\
\hline & & & & & \\
\hline$-1+$ & 5 & 8 & 0 & $\chi^{2}=4.24$ & \\
\hline$++/+++$ & 3 & 9 & 5 & $\mathrm{p}=0.04$ & \\
\hline
\end{tabular}

Percentages are the 50 th centiles in a frequency distribution.

$-/+$, negative/focally positive; $++/+++$, diffusely positive $(++$, moderate; +++ , strong).

$\mathrm{ISH}$, in situ hybridisation. cells as a cut off point, respectively. These percentages are the 50th centiles in a frequency distribution for $\mathrm{AP}-2 \alpha, \mathrm{AP}-2 \beta$, and $\mathrm{AP}-2 \gamma$. Because only some tumour cell nuclei showed AP- $2 \alpha$ positivity no statistical analyses were performed on nuclear staining.

\section{Results}

AP-2 PROTEIN EXPRESSION

In immunohistochemical analyses of AP-2 proteins, negative control sections remained negative, and in tumour sections strongly positive inflammatory cells served as internal controls. Mild cytoplasmic expression of AP$2 \alpha, \mathrm{AP}-2 \beta$, and $\mathrm{AP}-2 \gamma$ was constantly seen in normal colorectal epithelium. Tables 2 and 3 show the AP- $2 \alpha, \mathrm{AP}-2 \beta$, and AP- $2 \gamma$ expression patterns in colorectal adenocarcinoma (fig 1) and adenoma. Specifically, 18 of 30 adenocarcinomas were positive for AP- $2 \alpha$ and 28 of 30 were positive for AP- $2 \gamma$. In six of 30 adenocarcinomas AP-2 $\alpha$ expression was diffuse (over $50 \%$ positivity). AP- $2 \beta$ positivity was found in 29 of 30 adenocarcinomas and staining was diffuse in 14 of the 30 cases. There was a higher cytoplasmic AP- $2 \alpha$ percentage fraction of positive tumour cells in adenomas than in carcinomas. In addition, in adenomas the AP- $2 \beta$ percentage fraction was higher than that of AP- $2 \alpha$ or AP- $2 \gamma$ (table 3). In four of 30 carcinomas and in three of 13 adenomas some nuclei $(<5 \%)$ were $\mathrm{AP}-2 \alpha$ positive (tables 2 and 3 ).

AP- $2 \alpha$ mRNA EXPRESSION AND RT-PCR

Consecutive sections of each specimen, stained by the sense probe, remained negative throughout in ISH. Normal colorectal epithelium was slightly positive and the mRNA signal was seen intracellularly as distinct blue dots. Tables 2 and 3 show the frequency distribution of $\mathrm{AP}-2 \alpha$ mRNA in colorectal carcinomas and adenomas. AP- $2 \alpha$ mRNA was expressed moderately or strongly $(++$ and +++$)$ in 17 of 30 carcinomas (fig 2). In adenomas AP-2 mRNA values were generally lower (table 3 ). RT-PCR of AP- $2 \alpha$ mRNA and protein positive paraffin wax embedded tumour tissues confirmed that the positive signal in ISH originated from exon 2 of TFAP2A, instead of genomic sequences of $\mathrm{AP}-2 \beta$ or $\mathrm{AP}-2 \gamma$ or artefacts in tissue processing (fig 3 ). trophoresed on a $6 \%$ polyacrylamide gel and stained with silver nitrate.

STATISTICAL ANALYSIS

The SPSS-Win 7.5 program package was used for statistical calculations. The relations between $\mathrm{AP}-2 \alpha, \mathrm{AP}-2 \beta, \mathrm{AP}-2 \gamma$, and mRNA were analysed. Each parameter in the analysis was considered as a continuous variable. The interrelations between the categorical IHC and ISH variables and their associations with clinicopathological parameters were examined by contigency tables, which were further analysed by means of $\chi^{2}$ tests. In these analyses AP- $2 \alpha$, $\mathrm{AP}-2 \beta$, and $\mathrm{AP}-2 \gamma$ expression patterns were graded into two groups using $10 \%, 45 \%$, or $15 \%$ cytoplasmic staining positivity in cancer

\section{CORRELATION BETWEEN AP- $2 \alpha$ PROTEIN AND}

Similar AP- $2 \alpha$ protein and mRNA expression patterns were seen in 10 of 30 carcinoma specimens, including concordant mRNA and protein positive and negative tumour areas. Moderate or strong (++ and +++$)$ mRNA signals, despite negative $\mathrm{AP}-2 \alpha$ protein, were noted in seven of 30 carcinoma specimens. Diffuse positive AP- $2 \alpha$ staining (over $50 \%$ cytoplasmic positivity in tumour cells) and only focal $(+)$ mRNA expression were seen in three of 30 samples (table 2). In adenomas, six of 13 displayed similar mRNA and protein staining patterns (table 3). MRNA EXPRESSION 
CORRELATION BETWEEN THE AP-2 ISOFORMS, AP- $2 \alpha$ mRNA, AND CLINICOPATHOLOGICAL

PARAMETERS

Advanced Dukes's stage carcinomas had weaker cytoplasmic AP- $2 \alpha$ protein expression than low Dukes's stage tumours (table 4). $\mathrm{AP}-2 \alpha$ mRNA, and AP- $2 \beta$ and $\mathrm{AP}-2 \gamma$ protein values did not correlate with Dukes's stage. $\mathrm{AP}-2 \alpha$ and $\mathrm{AP}-2 \gamma$ values were inversely related to tumour grade. In contrast, greater positivity for AP- $2 \alpha$ mRNA was detected in high grade carcinomas (table 4). In adenomas there was no significant correlation between AP-2 protein and mRNA expression and the grade of dysplasia (data not shown).

\section{Discussion}

To date, only a few studies have examined the expression of AP-2 in human tumours. ${ }^{11} 17-192324$ Transfection of AP-2 into hepatoblastoma and colon adenocarcinoma cell lines that lack endogenous AP-2 expression has resulted in negative cell cycle control and tumour growth inhibition in vitro. ${ }^{2}$ Mild cytoplasmic expression of $\mathrm{AP}-2 \alpha, \mathrm{AP}-2 \beta$, and $\mathrm{AP}-2 \gamma$ was consistently seen in normal colorectal epithelium in our study. Our results revealed downregulated cytoplasmic AP-2 $\alpha$ expression in high grade and advanced Dukes's stage tumours. In addition, low cytoplasmic AP- $2 \gamma$ expression was seen in high grade carcinomas. These findings are in accordance with previous reports in which low AP-2 expression was associated with higher tumour malignancy and poor survival. ${ }^{17-19}$

According to recent studies, AP-2 is a potential new tumour suppressor gene. ${ }^{2} 3111824$ In malignant melanoma and breast cancer reduced nuclear AP-2 has been associated with poor prognosis. ${ }^{11}{ }^{18}$ However, the results shown in our study and in ovarian cancer by Anttila and colleagues ${ }^{19}$ suggest that reduced cytoplasmic AP- $2 \alpha$ expression also correlates with higher malignant potential. In our series AP- $2 \alpha$ expression was seen mainly in the cytoplasm but some nuclear positivity was also detected. $\mathrm{AP}-2 \beta$ and $\mathrm{AP}-2 \gamma$ were expressed only in the cytoplasm of the tumours. Both nuclear and cytoplasmic expression of AP- $2 \alpha$ has been observed in ovarian carcinomas, malignant melanomas, cervical intraepithelial neoplasms, and in childhood medulloblastomas, ${ }^{17-19}{ }^{23}$ as well as in our previous series of colorectal adenocarcinomas. ${ }^{25}$ The pattern of AP- $2 \alpha$ expression may be tumour type specific, because in breast cancer AP- $2 \alpha$ seems to be limited to cancer cell nuclei. ${ }^{11}{ }^{26}$ Because it is thought that the nuclear location of a transcription factor is essential for its functions, the mechanisms by which cytoplasmic AP-2 $\alpha$ and $\mathrm{AP}-2 \gamma$ mediate tumour suppression in colorectal cancer are still unknown. There are, however, other transcription factors, such as p5 $3^{27}{ }^{28}$ and BRCA $1,{ }^{29}$ which have also been described in the cytoplasm of cancer cells and have prognostic value.

Our study shows that approximately half of colorectal adenocarcinomas express AP- $2 \alpha$ mRNA moderately or strongly. However, in approximately a quarter of cases without $\mathrm{AP}-2 \alpha$ protein expression the presence of
mRNA was detected throughout the entire section. It is possible that in these cases AP- $2 \alpha$ mRNA was not adequately translated into protein, either because of impaired posttranscriptional processing of the mRNA transcript, ${ }^{30}$ or the repression of translation initiation, which is controlled by specific RNA-protein interactions. ${ }^{31}{ }^{32}$ Alternatively, spliced AP- $2 \alpha$ variants $^{31}$ or specific translation inhibitory elements ${ }^{33}{ }^{34}$ might function as translational repressors. Another possible explanation is premature truncation of the AP- $2 \alpha$ protein, which would affect antibody affinity or degradation of the AP- $2 \alpha$ protein. Our finding is supported by similar observations in malignant melanoma ${ }^{35}$ and in epithelial ovarian carcinoma. ${ }^{19} \mathrm{~A}$ discordance between urokinase (u-PA) and tissue (t-PA) plasminogen activator protein and mRNA values has also been seen in endometrial carcinoma, in which the amount of mRNA for both u-PA and t-PA in cancer tissues was much lower than was expected from the corresponding protein data. Evidently, high tumour tissue concentrations of these proteins did not result from transcriptional regulation, although the reduction of mRNA could indicate downregulation of transcription or possibly reduced mRNA stability. ${ }^{36}$

In conclusion, our results revealed reduced AP- $2 \alpha$ protein expression in colorectal carcinomas, and that reduced cytoplasmic AP- $2 \alpha$ and $\mathrm{AP}-2 \gamma$ protein expression correlated inversely with colorectal carcinoma malignancy. Adenomas were more often AP- $2 \alpha$ positive than carcinomas. Our ISH results also suggest that post-transcriptional events might effectively downregulate the expression of $\mathrm{AP}-2 \alpha$, although the growth suppressive mechanisms of AP-2 still remain largely unknown. In addition, the role of AP-2 in tumour growth is probably tissue specific. Additional studies will be required to clarify the role of transcription factors in cancer progression.

This study was financially supported by the EVO fund of Kuopio University Hospital. We thank Mrs A Ruotsalainen, Ms R Eskelinen, Ms R Pitkänen, and Ms H Kemiläinen for their skilful help in immunohistochemistry, in situ hybridisation, and RT-PCR analyses.

1 Gee MS, Sarkisian CJ, El-Deiry WS. Identification of a novel AP-2 consensus DNA binding site. Biochem Biophys Res Commun 1998;243:307-16.

2 Zeng Y-X, Somasundaram K, El-Deiry WS. AP2 inhibits cancer cell growth and activates p21/WAF1/CIP1 expression. Nat Genet 1997;15:78-82.

3 Bar-Eli M. Molecular mechanisms of melanoma metastasis. 7 Cell Physiol 1997;173:275-8.

4 Sers C, Kirsch K, Rothbacher U, et al. Genomic organization of the melanoma-associated glycoprotein MUC 18: implications for the evolution of the immu. 8514-18.

5 Huhtala P, Chow LT, Tryggvason K. Structure of the human type IV collagenase gene. F Biol Chem 1990;265: 11077-82.

6 Bosher JM, Williams T, Hurst HC. The developmentally regulated transcription factor AP-2 is involved in c-erbB-2 overexpression in human mammary carcinoma. Proc Natl Acad Sci U S A 1995;92:744-7.

7 Hennig G, Behrens J, Truss $M$, et al. Progression of carcinoma cell is associated with alterations in chromatin structure and factor binding at the E-cadherin promoter in vivo. Oncogene 1995;11:475-84.

8 Hennig G, Löwrick O, Birchmeier W, et al. Mechanisms identified in the transcriptional control of epithelial gene expression. F Biol Chem 1996;271:595-602.

9 Leask A, Byrne C, Fuchs E. Transcription factor AP-2 and its role in epidermal-specific gene expression. Proc Natl Acad Sci U S A 1991;88:7948-52. 
10 Mitchell PJ, Timmons PM, Hebert JM, et al. Transcription factor AP-2 is expressed in neural crest cell lineages during mouse embryogenesis. Genes Dev 1991;2:1557-69.

11 Gee JMW, Robertson JFR, Ellis IO, et al. Immunohistochemical analysis reveals a tumour suppressor-like role for the transcription factor AP-2 in invasive breast cancer. $f$ Pathol 1999;189:514-20.

12 Williamson JA, Bosher JM, Skinner A, et al. Chromosomal mapping of the human and mouse homologues of two new members of the AP-2 family of transcription factors. members of the AP-2
Genomics $1996 ; 35: 262-4$.

13 Gaynor RB, Muchardt C, Xia Y, et al. Localization of the gene for the DNA-binding protein AP-2 to human chromosome 6p22.3-pter. Genomics 1991;10:1100-2.

14 Foulkes WD, Ragoussis J, Stamp GW, et al. Frequent loss of heterozygosity on chromosome 6 in human ovarian carcinoma. Br F Cancer 1993;67:551-9.

15 Robertson GP, Coleman AB, Lugo TG. Mechanisms of human melanoma cell growth and tumor suppression by chromosome 6. Cancer Res 1996; 56:1635-41.

16 Trent JM, Stanbridge EJ, Mc Bride HL, et al. Tumorigenicity in human melanoma cell lines controlled by introduction of human chromosome 6. Science 1990;247:568-71.

17 Hietala KA, Kosma V-M, Syrjänen KJ, et al. Correlation of MIB-1 antigen expression with transcription factors Skn-1, Oct-1, AP-2, and HPV type in cervical intraepithelial neoplasia. F Pathol 1997;183:305-10.

18 Karjalainen JM, Kellokoski JK, Eskelinen MJ, et al Downregulation of transcription factor AP-2 predicts poor survival in stage I cutaneous malignant melanedicts poor Oncol 1998;11:3584-91.

19 Anttila MA, Kellokoski JK, Moisio KI, et al. Expression of transcription factor AP-2 $\alpha$ predicts survival in epithelial ovarian cancer. Br F Cancer 2000;82:1974-83.

20 UICC. In: Sobin LH, Wittekind C, eds. TNM classification of malignant tumours, 5th ed. New York: Wiley-Liss, 1997:66-9.

21 Turnbull RB, Kyle K, Watson FB, et al. Cancer of the colon: the influence of the no-touch isolation technique on survival rates. Ann Surg 1967;166:400-27.

22 Sugg S, Ezzat S, Rosen IB, et al. Distinct multiple RET/PTC gene rearrangements in multifocal papillary thyroid neoplasia. F Clin Endocrinol Metab 1998;83:4116-22.

23 Gilbertson RJ, Perry RH, Kelly PJ, et al. Prognostic significance of HER2 and HER4 coexpression in childhood medulloblastoma. Cancer Res 1997;57:3272-80.
24 Jean D, Gershenwald JE, Huang S, et al. Loss of AP-2 results in up-regulation of MCAM/MUC18 and an results in up-regulation of MCAM/MUC18 and an increase in tumour growth and metastasis of human melanoma cells. Fiol Chem 1998;

25 Ropponen KM, Kellokoski JK, Lipponen PK, et al. p21/WAF1 expression in human colorectal carcinoma: association with p53, transcription factor $\mathrm{AP}-2$ and prognosis. Br f Cancer 1999;81:133-40.

26 Turner BC, Zhang J Gumbs AA, et al. Expression of AP-2 transcription factors in human breast cancer correlates with the regulation of multiple growth factor signalling pathways. Cancer Res 1998;58:5466-72.

27 Bosari S, Viale G, Bossi P, et al. Cytoplasmic accumulation of p53 protein: an independent prognostic indicator in colorectal adenocarcinomas. 7 Natl Cancer Inst 1994;86:681-7.

28 Sun XF, Carstensen JM, Zhang H, et al. Prognostic significance of cytoplasmic p53 oncoprotein in colorectal adenocarcinoma. Lancet 1992;340:1369-73.

29 Chen Y, Chen CF, Riley DJ, et al. Aberrant subcellular localization of BRCA1 in breast cancer. Science 1995;270: $789-91$.

30 Kleijn M, Scheper GC, Voorma HO, et al. Regulation of translation initiation factors by signal transduction. Eur $\mathcal{F}$

31 Day DA, Tuite MF. Post-transcriptional gene regulatory mechanisms in eukaryocytes: an overview. F Endocrinol 1998;157:361-71

32 Buettner R, Kannan P, Imhof A, et al. An alternatively spliced mRNA from the AP-2 gene encodes a negative regulator of transcriptional activation by AP-2. Mol Biol 1993;13:4174-85.

33 Wang E, Ma W-J, Aghajanian C, et al. Posttranscriptional regulation of protein expression in human epithelial carcinoma cells by adenine-uridine-rich elements in the $3^{\prime}$ - untranslated region of tumor necrosis

34 Liu SY, Redmond TM. Role of the 3'-untranslated region of RPE65 mRNA in the translational regulation of the RPE65 gene: identification of a specific translation inhibitory element. Arch Biochem Biophys 1998;357:37-44.

35 Karialainen JM, Kellokoski JK, Mannermaa AJ, et al. Failure in post-transcriptional processing is a possible inactivation mechanism of AP-2 $\alpha$ in cutaneous melanoma. $\mathrm{Br} \mathcal{F}$ Cancer 2000;82:2015-2

36 Nordengren J, Casslen B, Gustavsson P, et al. Discordant expression of mRNA and protein for urokinase and tissue plasminogen activators (u-PA, t-PA) in endometrial carcinoma. Int $\mathcal{F}$ Cancer 1998;79:195-201.

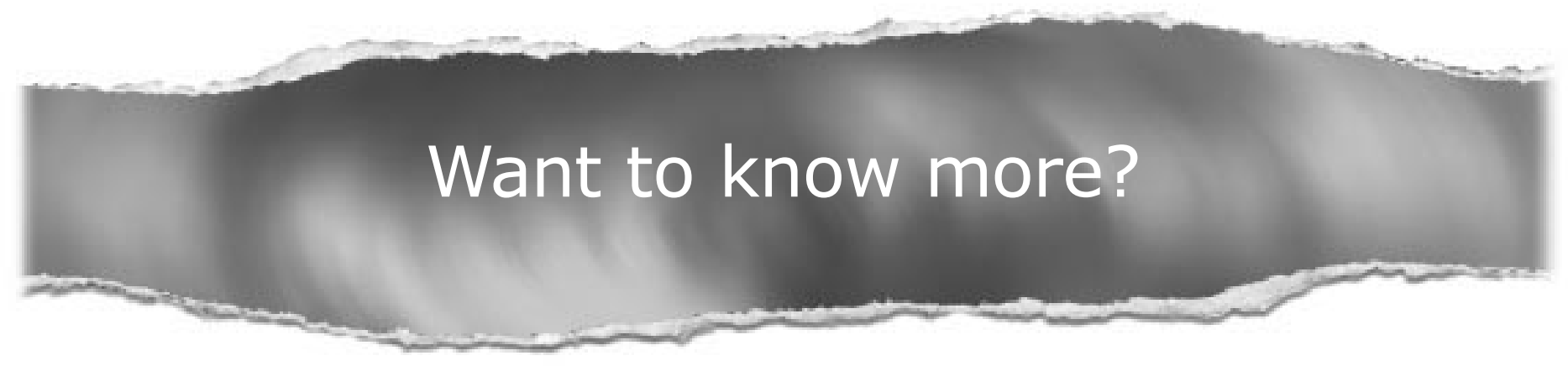

Data supplements

Limited space in printed journals means that interesting data and other material are often edited out of articles; however, limitless cyberspace means that we can include this information online.

Look out for additional tables, references, illustrations.

www.jclinpath.com 